\title{
Davranışsal İçgörü ve Halkla Ilişskilerin Kesişim Noktası: Çocuk Gelin Sorununda Medyada Farkındalık ve Davranışsal Halkla İlişkiler
}

Filiz Balta Peltekoğlu (Prof. Dr.)

Marmara Üniversitesi İletişim Fakültesi

filiz@marmara.edu.tr

Orcid: 0000-0001-6667-1737

Zuhal Akbayır (Arş. Gör. Dr.)

Marmara Üniversitesi İletişim Fakültesi

zuhal.akbayir@marmara.edu.tr

Orcid: 0000-0001-7267-4184

Başvuru Tarihi: 17.04.2019

Yayına Kabul Tarihi: 02.05.2019

Yayınlanma Tarihi: 22.07.2019

DOI: $10.17680 /$ erciyesiletisim.554861

Peltekoğlu, F. B. ve Akbayır, Z. (2019). Davranışsal İçgörü ve Halkla İlişkilerin Kesişim Noktası: Çocuk Gelin Sorununda Medyada Farkındalık ve Davranışsal Halkla İlişkiler. Erciyes İletişim Dergisi, 6 (2), 827-844. DOI: 10.17680/erciyesiletisim.554861

Öz

Davranışsal içgörü, temel amacı bireylerin davranışlarını anlamaya ve bireyleri hem kendileri hem de toplum için rasyonel tercihler yapmaya yöneltecek politika ve programlar üretmek olan bir çalışma alanıdır. Davranıșsal içgörü programlarıyla psikoloji, sosyoloji, ekonomi politika gibi çeşitli disiplinler bağlamında davranışsal yaklaşımlardanyararlanılmaktaveiletişimbilimlerinin desteğiilekamupolitikalarıyla ilgili toplumsal bilinç oluşturulmasına katkı sağlanmaktadır. Çocuk gelin ve çocuk evlilikleri sorunu ise sadece Türkiye' de yaşanan ve bireysel nitelikte çözüm bekleyen bir sorun değil, ekonomik, sosyal, psikolojik nedenleri ve sonuçları olan toplumsal ve evrensel çok boyutlu bir sorundur. Sorunun çözümü ise ekonomik önlemler ve hukuksal düzenlemelerin yanında konuyla ilgili farkındalık yaratılmasını, bireysel mücadele gücünün kazanılabilmesini, toplumsal bilincin oluşturulabilmesini gerektirmektedir. Bu çalışmada Türkiye'de çocuk gelin ve çocuk evlilikleri sorunu medyada temsili bağlamında incelenmiş ve sorunla mücadelede davranışsal içgörü programlarıyla desteklenen davranıșsal Halkla İlişkiler programlarının kamu politikaları içinde önemli bir aktör olduğu sonucuna varılmıştır.

Anahtar Kelimeler: Çocuk Gelin, Çocuk Evlilikleri, Davranışsal İçgörü, Davranışsal Halkla İlişkiler. 


\title{
Intersection of Behavioral Insights and Public relations: Media Awaraness of The Child Bride Issue and Behavioral Public Relations
}

Filiz Balta Peltekoğlu (Prof. Dr.)

Marmara University Faculty of Communication

filiz@marmara.edu.tr

Orcid: 0000-0001-6667-1737

Zuhal Akbayır (Res. Asst. Ph.D.)

Marmara University Faculty of Communication

zuhal.akbayir@marmara.edu.tr

Orcid: 0000-0001-7267-4184

Date Received: 17.04.2019

Date Accepted: 02.05.2019

Date Published: 22.07.2019

DOI: $10.17680 /$ erciyesiletisim.554861

\begin{abstract}
Behavioral insight is the study of understanding how people behave in practice and generating policy and programs to prompt individuals to make rational choices that will benefit themselves and the society as well. In the context of behavioral insight programme, disciplines like psychology, sociology, political economy are sought out to understand and generate consensus regarding public policy. The issue of the child bride is not only present in Turkey but one of a multidimensional global scale, which stems from and causes various economic, social and psychological reasons and outcomes. The solution to this pressing issue necessitates generating awareness about the issue and empowering girls to resist child marriage, as well as creating social consciousness about the causes and implications of child marriage. This study investigates the issues of child brides and child marriage in the context of media coverage in Turkey and concludes that Behavioral Public Relations programs targeting the issues which are supported by behavioral insight to be important actors within public policy.
\end{abstract}

Keywords: Child Marriage, Child Brides, Behavioral İnsight, Behavioral Public Relations 


\section{Giriş}

Günümüzde eğitimin geliştirilmesi, enerji ve kaynakların korunması, üretkenliğin arttırılması, sağlık alanındaki iyileştirmeler, yolsuzluğun azaltılması, şiddetle mücadeleye yönelik önlemler geliştirilmesi gibi konuların çözümünde davranış bilimlerinin önemi giderek artmaktadır. Bu bağlamda davranışsal bilgilendirme politikaları, karar verme ve davranış arasındaki ilişkinin önemini vurgulamakta, insanların düşündükleri ve eyleme geçtikleri konuları etkileyen sosyal, psikolojik ve ekonomik faktörlere dikkat çeken geniş bir etki kümesini incelemektedir (The World Bank, 2018).

Devletler açısından kamu politikaları kapsamında ele alınan sorunların çözümü yasal düzenlemeler gerektirir, ancak bireylerde davranış değişikliği oluşturabilmek için farkındalık yaratmak, karar sürecinde rol oynayan temel motivasyonları ortaya koymak, bilgilendirmekve ikna edici iletişim süreçlerinden yararlanmak politikaların kabul görebilmesi açısından önemlidir.

Bireylerde kamu politikaları kapsamındaki sorunların çözüm önerilerinin kişisel yaşamlarına sağlayacağı katkıya inanarak rasyonel temellere dayalı davranış değişikliği yaratılması,-davranışsal içgörü programlarının temel amacıdır. Bu nedenle davranışsal içgörü politikalarıyla buluşan Halkla İlişkiler çabalarının yüklendiği sorumluluk, toplumsal sorunlarla mücadele ve kamu politikaları açısından önemli role sahiptir.

Flynn'a göre, kamu politikaları iletişimi, mesaj direncine ve kamuoyunda kutuplaşmaya karşı yararlanılması gereken bir alandır. Yine Flynn'a göre kamu politikalarında ikna edici ve rasyonel verilere dayalı güvenilir bilgilendirme kampanyaları yaşamsal önem taşır (Flynn, 2015). 1900'lerin ilk yarısından bu yana Kamuyu bilgilendirme - İki yönlü asimetrik modellere dayanan halkla ilişkiler uygulamaları da toplumsal ve psikolojik araştırmaların desteklediği kapsamlı hedef kitle analizlerini odağına yerleştirerek hareket etmektedir. Bu bilgi ışığında Halkla İlişkilerin, davranıșsal içgörü programları kapsamında bireyleri kendileri için doğru ve rasyonel seçimler yapmaya yöneltebilecek bir potansiyeli, işlevi ve sorumluluğu olduğu söylenebilir.

Çocuk gelin ve çocuk evlilikleri sorunu ise sağllk, eğitim, ekonomik hak ve özgürlüklerden yoksun kalmaya neden olan, toplumsal kalkınmayı olumsuz yönde etkileyen ve cinsiyet eşitsizliğinin önünde aşılması gereken bir engeldir. Bu nedenle çocuk gelin sorunu erken yaşta evliliğe maruz kalan kişinin karşılaştığı sağlık, eğitim, ekonomik haklar, cinsiyet eşitliği, kültürel vb. alanlardaki sonuçlarıyla çözüm bekleyen çok boyutlu sorunlar bileşkesidir. Bu yaklaşımla çocuk gelin - çocuk evlilikleri sorununun ekonomik, hukuksal ve sosyolojik yönleriyle kamu politikaları kapsamında ele alınması, soruna davranışsal içgörü ve Davranışsal Halkla İlişkiler programları bağlamında çözüm üretilmesi gerekir.

\section{Davranışsal İçgörü, İletişim ve Halkla İlişkiler}

Davranışsal içgörü, politika geliştirmek amacıyla psikoloji, bilişsel faktörler ve sosyal bilimlerin amprik olarak test edilmiş sonuçlarını insanların karar verme süreçlerini anlamak için birleştiren bir tüme varım yaklaşımıdır (OECD, 2018'den akt. Balta Peltekoğlu, 2018, 583). OECD (Ekonomik Kalkınma ve İşbirliği Örgütü), "daha iyi yaşam için daha iyi politikalar" (Better Policies for Better Lives) sloganıyla davranıșsal 
içgörüye dikkat çekerken, İngiltere'de Davranışsal İçgörü Takımı, Kuzey Amerika ve gelişmiş diğer ülkelerde kamu hizmetlerini daha etkili ve daha kolay kullanılabilir olması için insan davranışlarına ilişkin daha gerçekçi modeller geliştirerek çıktıları iyileştirmek, insanları hem kendileri hem de toplum için daha iyi tercihler yapma konusunda bilinçlendirmek amacındadır (The Behavioral Insights Team, 2018).

Davranışsal içgörü yaklaşımıyla karar verme süreci bireysel, çevresel ve sosyal faktörlerden etkilenir. Davranışsal içgörüde bireysel faktörler, insanların algılayabileceklerinden daha fazla bilgi ile karşılaștıklarını anlamanın yanında, karmaşık görevleri, süreçleri ve politikaları basitleştirmenin önemini vurgulamaktadır. Çevresel faktörler, insan davranışının çoğunun çevre tarafından şekillendirildiği gerçeğinden yola çıkmaktadır. $\mathrm{Bu}$ nedenle, bireyleri istenen davranışlara yönlendirmek için web siteleriyle forumlara eklenen ipuçlarının önemi büyüktür. Sosyal faktörler ise kişilerarası ilişkilere verilen önemi açıklamaktadır. Bireyin kendi davranışları ile karşısındakinin davranışlarını karşılaştırarak iyi ve rasyonel olan davranışları sergilemeye yönelik amaçlarla motive edilmesi davranışsal içgörü programlarının temel hedeflerindendir (Internal Revenue Services, 2016).

Davranışsal içgörü, deneysel yöntemlerle elde edilen ampirik olarak test edilmiş sonuçlara dayalı olarak oluşturulan politikalar ve yönetmelikler aracılığıyla vatandaşların ve tüketicilerin refahını iyileştirmeyi amaçlamaktadır. Bu nedenle davranışsal içgörü insanların farklı koşullar altında nasıl düşündüklerini, nasıl davrandıklarını ve nasıl karar verdiklerini anlamak için; psikoloji, nörobilim ve diğer sosyal bilimlerden gelen bakış açılarıyla, davranışları değiştirmeye yönelik geleneksel ekonomik stratejileri birleştirir ve bu yaklaşımları,davranışsal içgörü programlarının ve hizmetlerinin tasarımını ve sunumunu geliştirmek için kullanır (Behavioral Insights in, 2018). Davranıșsal içgörü kapsamında davranışsal ekonomi, sosyal ve bilişsel psikoloji ve antropoloji gibi çeşitli disiplinlerden yararlanılmaktadır (EU Science HUB, 2018). Günümüzde dünya genelinde kamu ve özel sektör olmak üzere toplam 196 kurum ve kuruluş davranışsal içgörü kavramını politikalarına dahil etmektedir (OECD, 2018).

Davranışsal içgörü programlarını tüm dünyada farklı alanlara uygulayabilen birimler görmek mümkündür. Nitekim 2016 yılında, Birleşmiş Milletler Kalkınma Programı İnovasyon Merkezi, 5 bölgedeki 8 BMKP (Birleşmiş Milletler Kalkınma Programı/ UNDP) Ülke Ofisi ve Birleşmiş Milletler Davranış Bilimi Danışmanlığı ile Bangladeș, Kamerun, Çin, Ekvador, Ürdün, Moldova, Karadağ ve Papua Yeni Gine'de davranışsal içgörü üzerine bir pilot-program başlatmıştır. Bu program, sürdürülebilir kalkınma hedeflerine ulaşmaya yardımcı olmak için davranışsal içgörünün potansiyelini ortaya koymayı hedeflemektedir. Birleşmiş Milletlerin "2030 Gündemi” kapsamında beş geniş alanda davranışsal iç görü kavramının etkisini uyguladığı ve test ettiği girişimler; cinsiyet eşitliğinin ve kadınların güçlendirilmesinin geliştirilmesi, mültecilere ve göçmenlere yönelik beceri değişimleri ve istihdam olanakları sağlamak, gezegeni korumak, risk yönetimi ve esnekliğin inşası, şiddetli çatışmaları önleme ve barıșçıl toplumlar inşa etme șeklinde sıralanmaktadır (UNDP, 2018).

2016 yılından bu yana İngiltere Halkla İlişkiler meslek örgütü IPR (Institute for Public Relations) davranışsal içgörü konusunda çalışmalar yürüten Davranışsal İçgörü Araştırma Merkezi’ni (Behavioral Insights Research Center) faaliyete geçirmiştir. 
Örgüt merkezin amacını "tutum ve davranış değişikliği yaratacak iletişim stratejilerine etki eden faktörler konusunda araştırmalar gerçekleştirmek" olarak tanımlamakta, karar verme ve değerlendirme, bellek ve öğrenme, anlatılar ve ikna, bilişsel ve sosyal nöroloji gibi konular üzerinde çalışmalar yürütmektedir (IPR, 2018).

Birleşik Krallık hükümeti tarafından desteklenen Davranışsal İçgörü Ekibi (Behavioral Insights Team) Londra merkezli faaliyetlerini, yaklaşık 150 çalışanı ile dünya çapında birçok ülkede yürütmektedir. Davranışsal içgörü ekibi, faaliyet amaçlarını kamu hizmetlerinin vatandaşların kullanımı için daha uygun maliyetli ve daha kolay hale getirilmesi; daha gerçekçi davranış modelleriyle politikaların sonuçlarını iyileştirmek; ve mümkün olan her yerde insanların "kendileri için daha iyi ve rasyonel seçimler" yapmalarını sağlamak olarak sıralamaktadır (The Behavioral Insights Team, 2018). Bu yaklaşımla davranışsal içgörü programlarının geliștirilmesi ve uygulanmasıyla toplumsal sorunların çözümüne katkı sağlanabileceği kabul edilmektedir. Söz konusu çalışmalar toplumsal sorunların çözümünde psikolojik faktörlerin yanı sıra iletişim boyutunun da önemini ortaya koyar niteliktedir. Bu nedenle davranışsal içgörü programlarının geliştirilmesi ve gerçekleştirilmesi sürecinde bireysel ve toplumsal düzeyde gerçekleştirilecek iletişimin, sorunun anlaşılması ve çözüm önerilerinin anlatılması amaçlarıyla yönetilmesi gerekir.

ABD Çalışma Bakanlığı davranışsal içgörü çalışmalarında mesajda etkinlik sağlanması için gereken iletişim kontrol listesinde mesajın anlaşılabilir olmasının, önemli bilgilerin öncelikli aktarılmasının ve mesajın kişiselleştirilmiş olmasının gerekliliğine dikkat çekmektedir (US Department of Labour, 2018). Mesajın anlaşılabilir olmasını ve öncelikli bilgilerin göz önünde tutulmasını sağlayan birçok Halkla İlişkiler araç ve yöntemini sıralamak mümkündür. Davranışsal içgörü programlarının temel hedeflerinden bir tanesi mesajın hedef kitlenin direnişiyle karşılașması durumunda direnișe yönelik hızlı cevap verebilme stratejilerine sahip olmaktır. Mesajın tutuma yönelik hedeflediği değişim, alıcının mevcut zihinsel çerçevesiyle tutarsız olursa, kişinin tutarlılığına yönelik tehditlere bir cevap olarak direnç ortaya çıkar. Flynn'a göre davranışsal içgörü programlarında direncin üstesinden gelecek acil iletişim yöntemlerinden biri ikna edici anlatıdır. Bir mesajın bir öykü olarak sunulması bilişsel süreç içinde direnci azaltabilir. $\mathrm{Bu}$ bağlamda Flynn'a göre, temel direnç türleri ve davranışsal içgörü kapsamında yararlanılan etkili iletişim biçimleri şunlardır (Flynn, 2016); Karşıt Sav Geliştirme (Counterarguing); Bir mesajın içeriğine yönelik karşıt fikirlerin üretilmesidir. Alıcının, ikna edici anlatının karakterleriyle özdeşleşmesinin sağlanması ise karşıt fikirlerle oluşan direnci azaltabilir. Mesajı Küçümseme (Message minimization); mesajı küçümseme yoluyla mesajın önemi en aza indirilmektedir. Davranışsal içgörü programlarında mesajın akla yatkın, gerçekçi ve inandırıcı bir şekilde sunularak mesajın gerçek dünyayı yansıttığı olasılığını vurgulamak, bir mesajın önemsenmesini ve mesaj iletme sürecinin doğru bir şekilde ilerlemesini sağlayacaktır. Olumsuz sonuç beklentileri (Negative outcome expectancies); Dirençli bireyler davranış değișikliğine yönelik yanlış ve olumsuz beklentiler oluşturabilirler. Arzu edilen davranışı sergileyen karakterlerin tanımlanması yoluyla, alıcıların davranış modellemesine benzer şekilde davranmaları teşvik edilebilir. Tepki (Reactance); Bireyler ikna edici mesajları kendi düşünceleri üzerinde görerek bireysel kontrolüne tehdit olarak algılayabilirler. Anlatılar ikna etme niyetini geri plana atarak ve alt 
metin okumaları içeren bilişsel kaynakları sınırlayarak tepkiyi azaltabilir. Seçici kaçınma (Selective avoidance); Bazı durumlarda alıcı, mesajın tamamını veya bir kısmını bilinçli olarak görmezden gelebilir. Karakterlerle özdeşleştirilmiş, eğlenceli anlatılar mesajın kabul edilmesinde motive edici olabilir.

Davranışsal iletişimin sözü edilen özellikleri Halkla İlişkilerin psikoloji bölümünden aldığı desteği ve ikna kavramı ile ilişkisini akla getirir niteliktedir. Nitekim IPR bünyesinde yer alan Davranışsal İçgörü Araştırma Merkezinin kendi çalışma alanını tanımlama biçimi de, kavramın Halkla İlişkiler disipliniyle ilişkiyi ortaya koyar niteliktedir. Patrick Jackson ise, davranış değişikliği üzerine odaklanan Halkla İlişkiler modelinde beş temel adımdan söz etmektedir; farkındalık oluşması, insanların edindikleri bilgiler üzerinde düşünmeye başladıkları örtük ilgi süreci, örtük ilginin Halkla İliş̧kiler etkinlikleriyle tetiklenmesi, nihai davranış öncesi küçük bazı tutum ve davranış değişiklerinin yaşanması ve nihayet davranış değişikliğinin gerçekleşmesi. Patrick Jackson'un modeli açısından bakıldığında söz konusu adımların Halkla İlişkilerin disiplinlerarası niteliğini de ortaya koyduğu görülmektedir. Nitekim bağımsız bir disiplin olarak Halkla İlişsilerin siyaset, ekonomi, iletişim kuramları ve yöntemleri yanında psikoloji ve davranış bilimleri gibi disiplinlerden beslenmesi (Balta Peltekoğlu, 2000'den akt. Balta Peltekoğlu, 2005,123) Davranışsal Halkla İlişkilerin etkililiğinin de temel anahtarıdır.

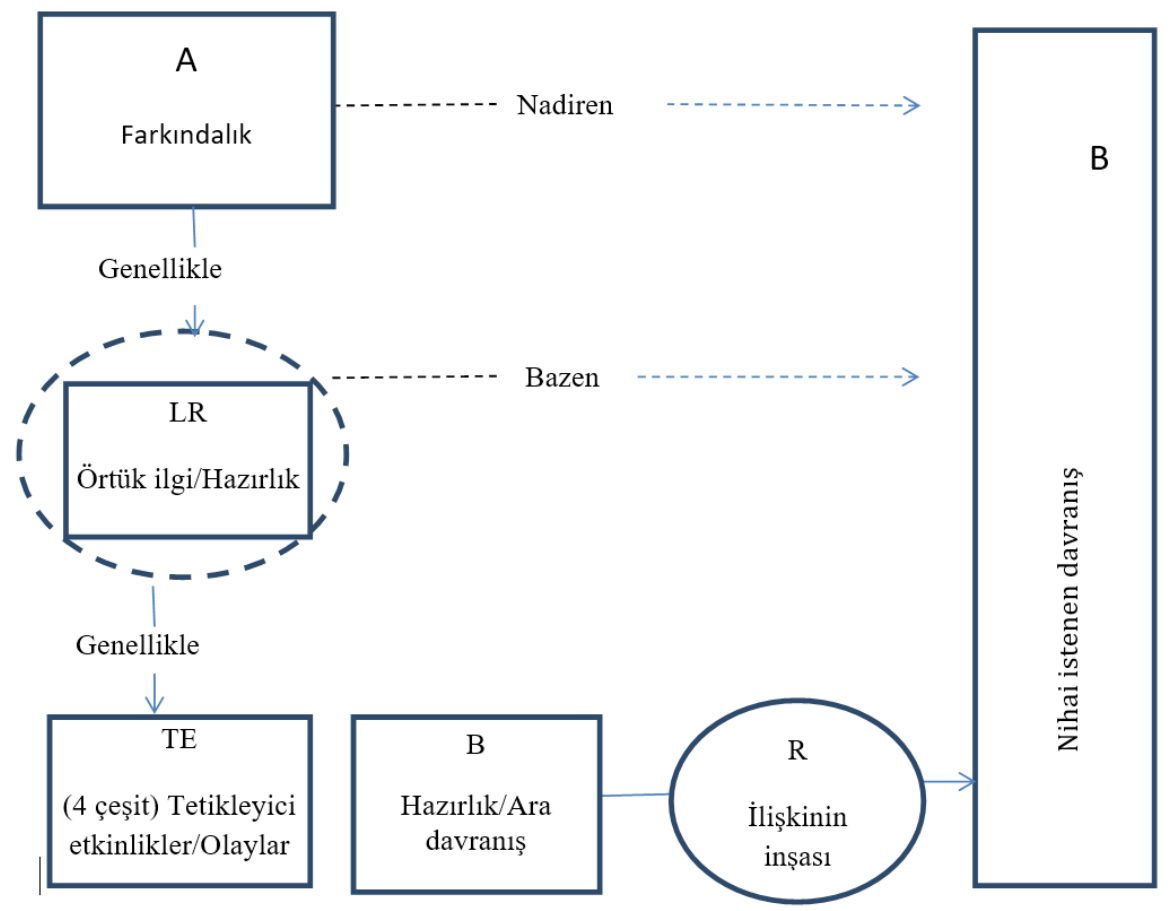

Şekil 1: Patrick Jackson Davranışsal Halkla İliş̧iler Modeli Kaynak: Center, Jackson, Smith, Stansberry, 2008, 14

Patrick Jackson'un Davranışsal Halkla İlişkiler Modeli olarak ifade ettiği yaklaşımda ilk adım olan farkındalığın oluşturulmasını, insanların konu üzerinde düşünmeye başladığı ve davranış değişikliğinin bir potansiyel haline geldiği örtük ilginin yaratılması aşaması izlemektedir. Düşüncenin eyleme dönüşmesini sağlayan bazen doğal, bazen planlı olarak gerçekleştirilen tetikleyici etkinlikler/ olaylar Jackson'un Halkla İlişkiler modelinin üçüncü adımıdır. Jackson'a göre ilginin tetiklendiği bu adımı, davranış değişikliğinin öncülü olan ve iletilere duyarsız kalınmadığı, broşür ve 
iletişim materyallerine ilginin olduğu, etkinliklere katılımın gerçekleştiği dördüncü adımı ise programın nihai hedefi olan davranış değişikliği izleyecektir (Center vd., 2008, 15-16). Davranıșsal Halkla İlișkiler Modeli, Halkla İlişkilerin holistik bir bakış açısıyla değerlendirilmesini gerekli kılar. Halkla İlişkilerin disiplinlerarası olması, hemen her alana uygulanabilirliği ve iletişimle açığa çıkma özelliğinin (Balta Peltekoğlu, 2016, 369) dikkate alınması, toplumsal sorunların çözümündeki işlevini de belirgin hale getirir. Örneğin Davranışsal Halkla İlişkiler programları Birleşmiş Milletler'in (BM) "2030 Gündemi” kapsamında davranışsal içgörü kavramının etkisini uyguladığı ve test ettiği girișimlerden olan cinsiyet eșitliğinin ve kadınların güçlendirilmesinin geliştirilmesi ve BM Binyıl Kalkınma Hedefleri arasında yer alan anne - çocuk ölümlerini azaltmak, cinsiyet eşitliği, eğitim gibi toplumsal refahı doğrudan etkileyecek pek çok konuda katkı sağlayabilir. Daha önceki yıllarda iknaya dayalı olarak tanımlanan, iki yönlü asimetrik modelle açıklanan ve toplumsal sorunlara çözüm üreten uygulamaların ise, davranışsal Halkla İlişkiler anlayışının ilk sesleri olduğu söylenebilir. Bu yaklaşımla Halkla İlişkilerin davranış değişikliği yaratmaya yönelik uygulamalarını sınırlı sayıda örnekler bağlamında ele alarak, disiplini manipülatif olarak değerlendiren yaklaşım, disipline karşı bir haksızlık olacağı gibi aynı zamanda eksik bir değerlendirmedir. Nitekim “Davranışsal Halkla İlişkiler" kavramı, Halkla İlişkilerin toplumsal sorunlara çözüm üreterek toplumsal kalkınmaya katkı sağlamak amacıyla davranış değişikliği yaratma konusundaki çabalarını kapsar ve açıklar. Toplumsal kalkınmaya yönelik programların kabulü ve benimsenmesi sürecinde, Davranışsal Halkla İlişkilerle rasyonel karar alma sürecine katkıda bulunulması, mesleki olduğu kadar ahlaki bir sorumluluk ve zorunluluktur. Zira günümüz demokratik toplumlarında gerek duyulan davranış değişikliğinin gerçekleşebilmesi için yasal düzenlemelerin yeterli olmayacağı ve toplumsal bilincin geliştirilmesi için bilgilendirmenin gerektiği konusundaki fikir birliğinden söz edilebilir. Bu bilgiler ışığında davranışsal içgörü yaklaşımıyla Halkla İlişkilerin, demokratik toplumlarda kalkınma odaklı kamu politikalarına eșlik etmesi bir gerekliliktir. Bu nedenle Türkiye'de toplumsal bir sorun olarak çocuk yașta yap(tırı) ılan evliliklerin önlenebilmesi için Davranışsal Halkla İlişkilerin önemli bir aktör rolünü üstlenebileceği söylenebilir.

\section{Evrensel ve Toplumsal Bir Sorun Olarak Çocuk Gelin ve Çocuk Evlilikler}

18 yaşın altında yapılmış her evlilik "çocuk evliliğì", evlenen kız çocuğu ise "çocuk gelin" olarak tanımlanmaktadır (Noul, 2009). Nitekim Türkiye'nin de taraf olduğu Uluslararası Çocuk Hakları Sözleșmesi'ne göre “Daha erken yașta reșit olma durumu hariç, on sekiz yaşına kadar her insan çocuk sayılmaktadır" (Çocuk Haklarına Dair Sözleşme, 1989). Türkiye'de 3/7/2005 tarihli Çocuk Koruma Kanununa göre, "Daha erken yaşta ergin olsa bile, on sekiz yaşını doldurmamış kişi” çocuk olarak tanımlanmaktadır (Çocuk Koruma Kanunu, 3/7/2005).

United Nations International Children's Emergency Fund (UNICEF) verilerine göre dünya genelinde genç kadınların yüzde 21 oranında, genç erkeklerin ise yüzde 4 oranında 18 yaşından önce evlendikleri belirlenmiştir. Her yıl 18 milyon genç kızın 18 yaşın altında evlendiği ve çocuk evliliklerini önleme girişimleri hızlandırılamazsa 2030 yılına kadar 150 milyon çocuğun daha 18 yaşından önce evleneceği öngörüsü ortaya konmuştur. Dünyada en fazla çocuk evliliklerinin görüldüğü ülkeler ise, Nijerya (yüzde 76), Orta Afrika Cumhuriyeti (yüzde 68), Çad (yüzde 67), Bangladeş (yüzde 59)' dir (Child Marriage Around, 2018). 
Çocuk evlilikleriyle ilgili ortak toplumsal bilinç geliştirmek, çocuk evliliklerin nedenlerini ortadan kaldırmak ve sonuçlarını önlemek amacıyla mücadele eden pek çok uluslararası kuruluş ve faaliyetten söz edilebilir. Örneğin kız çocukların evliliğine karşı faaliyetler yürüten "Girls Not Brides" adlı sivil toplum örgütünün verilerine göre her yll dünyada 12 milyon kız çocuğu 18 yaşından önce evlenmektedir. Bu ise her bir dakikada $23 \mathrm{klz}$ çocuğunun erken evlilik yaparak kişisel gelişimini ve refahını riske attığı anlamına gelmektedir (Girls Not Brides, 2018). BM'ye göre ise rakamlar daha da yüksektir, her gün 18 yaş altında $37.000 \mathrm{kız}$ çocuk evlendirilmektedir. Küresel olarak, 20-49 yaşlarında olan yaklaşık 400 milyon kadın 18 yaşından önce evlenmiştir. Gelişmekte olan ülkelerde $3 \mathrm{kuz}$ çocuğundan biri 18 yaşından önce, 9 kız çocuğundan biri 15 yaşından önce evlenmiştir. Mevcut eğilimler devam ederse, önümüzdeki on yılda 140 milyondan fazla kız çocuğunun 18 yaşından önce evleneceği tahmin edilmektedir (IWHC, 2018).

Türkiye'de 16 yaşına altındaki çocuk evlilikleri resmi olarak kayıt altına alınamamaktadır.

TÜIK'in (Türkiye İstatistik Kurumu) 2017 evlenme istatistiklerine göre; 16-17 yaş grubunda olan kız çocuklarının evliliğinin oranının toplam resmi evlenmeler içinde yüzde 4,2'dir. İl bazında incelendiğinde 2017 yılında Ağrı ili \%16,6'lık oran ile kız çocuk evlenmelerinde en üst sırada yer almakta, bu ili yüzde 16,1 ile Muş ve yüzde 12,3 ile Bitlis izlemektedir (İstatistiklerle Çocuk 2017, 2018). Yine TÜiK raporlarına göre, 2017 yılında 569.459 evlilik yapıldığı göz önüne alındığında söz konusu yüzde 4,2'lik oran, 2017 yılında 18 yaş altı çocuk evliliklerinin sayısının 23.917 olduğunu göstermektedir. TÜíK verilerine göre, 2016 ve 2017 ylllarında kız çocuk evlenmelerinin toplam evlenmeler içindeki oranının en düşük olduğu iller ise sırasıyla Tunceli, Rize, Trabzon'dur. (2017 yllı raporunda yüzde 0,4 ile Tunceli, yüzde 1,1 ile Rize ve yüzde 1,4 ile Trabzon, 2016 yllı raporunda yüzde 1 ile Tunceli, yüzde 1,5 ile Rize ve yüzde 1,6 ile Trabzon). Resmi evlenmelerin en az olduğu her 3 ilde kız çocukların eğitime katılım oranları incelendiğinde elde edilen veriler dikkat çekicidir. 2016-2017 eğitim-öğretim yılında ortaöğretim seviyesindeki kız çocuklarının net okullaşma oranının yüzde 100 ile en yüksek olduğu il Rize'dir (İstatistiklerle Çocuk 2016, 2017). TÜíK tarafından 2015 yılında gerçekleştirilen illerde yaşam endeksi raporuna göre, Tunceli'de kız çocuklarının okullaşma oranı yüzde 100'dür (Hürriyet gazetesi, 2016). TÜIK İstatistiklerle Çocuk 2017 raporuna göre ise, Trabzon ortaokul çağındaki kız çocuklarının okullaşması sıralamasında Türkiye'deki tüm iller arasında 4. sırada yer almaktadır (Veri Kaynağı, 2018). Söz konusu veriler ışığında kız çocuklarının okullaşma oranı ile çocuk evlilikleri arasında ters orantı olduğu görülmektedir. Bir başka deyişle TÜíK verileri, Türkiye'de okullaşma oranının yüksek olduğu illerin, çocuk evlilik ve çocuk gelin oranlarının en düşük iller olduğunu ortaya koymaktadır.

Erkek çocukların da evlilikleri söz konusu olmakla birlikte; 2007 yılında Nüfusbilim Derneği ve Birleşmiş Milletler Nüfus Fonu iş birliği ile gerçekleştirilen Türkiye Gençlerde Cinsel Sağlık ve Üreme Sağlığı Araştırması'na göre (TGCSÜSA) hane halkı nüfusu içinde yer alan 15-19 yaş grubunda erkekler arasında halen evli olanların oranı yüzde 1'in altında iken bu oran kadınlarda yüzde 7,5'dir (Nüfus Bilim Derneği, 2007). 22/11/2001 tarihli Türk Medeni Kanun'un 124. Maddesi'nde de evlilik yaşı düzenlenmiştir. Kanunda; "erkek veya kadın on yedi yaşını doldurmadıkça evlenemez. Ancak, hâkim olağanüstü durumlarda ve pek önemli bir sebeple on altı yaşını 
doldurmuş olan erkek veya kadının evlenmesine izin verebilir. Olanak bulundukça karardan önce ana ve baba veya vasi dinlenir" ifadesi yer almaktadır (Türk Medeni Kanunu, 22/11/2001). Türk Ceza Kanunu'nun 104. Maddesine göre "Cebir, tehdit ve hile olmaksızın, onbeş yaşını bitirmiş olan çocukla cinsel ilişkide bulunan kişi, şikayet üzerine, iki yıldan beş yıla kadar hapis cezası ile cezalandırılır". (Türk Ceza Kanunu, 26/09/2004). Yasanın bu maddesinde yer alan "şikayet üzerine" ifadesi şikayetin söz konusu ol(a)madığı durumlarda cezayı tartışmalı hale getirmektedir. Kaldı ki ekonomik ve sosyolojik sorunlarla baş etme yetisinin henüz tam olarak gelişmediği bir çağda şikayet konusu daha da dikkat çekici nitelik kazanmaktadır.

\section{Çocuk Gelin ve Çocuk Evliliklerinin Nedenleri ve Sonuçları}

Dünyada çocuk evliliklerinin nedenleri ülkeler, kültürel topluluklar ve coğrafi bölgeler arasında değişiklik göstermektedir. Sosyal antropoloji, feminist teori bağlamında da tartışılan çocuk gelin ve çocuk evlilikleri sorununun nedenleri, sosyolojik araştırmalarda ekonomik nedenler, gelenek, görenek ve inanışlar ile ataerkil aile yapısı gibi nedenler bağlamında ele alınmaktadır.

UNICEF tarafından çocuk haklarına yönelik bir şiddet sorunu (Child Marriage, 2018) olarak ele alınan çocuk evlilikleri sağlık sorunları, eğitim hakkından yoksun bırakılma, fiziksel ve ruhsal şiddetle karşı karşıya kalma, cinsiyet eşitsizliği gibi bireysel ve toplumsal sonuçları beraberinde getirmektedir. Çünkü çocuk gelinler sağlık, eğitim ve sosyal güvence gibi temel ve sosyal haklardan yoksun kalırlar. Çocuk gelinlerin HIV ve diğer (IWCH, 2018) bulaşıcı hastalıklara yakalanma riski ve anne - çocuk ölümlerinin yaşanması olasılığı daha yüksektir. (Nour, 2009, 51; Raj, 2010, 931). UNICEF'in Dünya Çocuklarının Durumu 2009 raporuna göre, eğer bir anne 18 yaşın altındaysa, bebeğin yaşamının ilk yılında ölme riski, 19 yaşından büyük bir anneden doğan bebeklerden yüzde 60 daha fazladır. Çocuk gelin sorunu aile içi şiddet riskini de artırır (IWCH, 2018).

Eğitim ise tüm nedenler ve sonuçlarla etkileșen bir konu olarak sorunun çözümünün odağında yer almaktadır. Nitekim uluslar arası örgütler tarafından yürütülmekte olan davranışsal içgörü programlarının eğitimi öncelikli konu olarak ele aldıkları görülmektedir. Okula gitmeyen kız çocuklar erken evlen(diril)ebilecekleri gibi, erken evlen(diril)en kız çocuklar da eğitim hakkından yoksun kalmaktadır. Söz konusu etkileşim çocuk evliliğinin toplumsal açıdan olumsuz etkilerini daha da ağırlaştırmaktadır.

\section{Çocuk Gelin ve Çocuk Evlilikleriyle Mücadelede Uluslararası Davranışsal İçgörü Programları}

Siyasal nedenlerle ülkeler arası göçlerin giderek artması, teknolojik gelişmeler ve küreselleşmenin etkilerinin giderek daha çok hissedilmesi gibi nedenler toplumsal sorunların evrensel niteliğe dönüşmesini hızlandırmaktadır. Bu yaklaşımla çocuk gelin ve çocuk evlilikleri sorunu insan ve kadın hakları açısından önemli olduğu kadar, sonuçlarının küresel boyutta yaratacağı etkiler açısından da evrensel çapta çözüm gerektirmekte ve uluslararası örgütlerin konuyla ilgilenmelerine, sorunun çözümüne yönelik projeler geliştirmelerine neden olmaktadır.

Hindistan merkezli Breakthrough, Global çapta faaliyet gösteren CARE-Global ve Girls Not Brides, Mısır'da çalışmalar yürüten Egyptian Foundation for Advancement of the Childhood Condition, Tanzanya merkezli Forum for African Women 
Educationalists, İngiltere merkezli Forward bunlardan birkaçıdır (The Pixel Project's, 2013). Bu örgütler kız çocuklarının okula devam etmeleri konusunda cesaretlendirilmeleri, cinsellik konusunda yaşa uygun eğitime sahip olmaları, risk altındaki kız çocukları için devlet korumasında barınma olanakları sağlanması, dini liderlerin desteğinin alınması, toplumsal diyalog geliştirilmesi, asgari yasal evlilik yaşının 18 olması için çalışmalar yürütmekte, kamuoyu liderlerinin eşlerinin de dahil olduğu projeler geliștirmektedirler. UNICEF ile Birleșmiş Milletler Nüfus Fonu (UNFPA), Güney Asya, Afrika ve Orta Doğu'da 12 yüksek risk ülkesini merkezine alarak, "Çocuk Evliliğini Sona Erdiren Eylemi Hızlandıracak Küresel Program" (Global Programme to Accelerate Action to End Child Marriage) adı verilen ve 246 milyon dolarlık bütçeye sahip bir davranışsal içgörü programını uygulamak için ortaklık kurmuştur. Bu küresel programın amacı, çocuk evliliğine karşı kızların kendi geleceklerini seçmelerini ve yönetmelerini sağlamaktır. Program bu konuda kız çocuklara yönelik olumlu tutum sergileyen hane halkını desteklemekte ve ergenlik çağındaki kızlara destek veren sistemleri güçlendirmeyi hedeflemektedir. Küresel program, 2019 yılının sonuna kadar çocuk evliliği riski altında 12 hedef ülkede, 2,5 milyon kıza doğrudan erişme potansiyeline sahiptir. Amacı, 2019 yılına kadar ortaokul çağındaki 179.000 kız çocuğunu daha pilot olarak seçilen okullarda tutmaktır. Bu amaçla United Nations Behavioral Insights (UNBI), UNICEF ve UNFPA, diğer dini liderleri ve onların bağlı olduğu toplulukları etkilemek ve çocuk evliliğine karşı olan dini liderleri güçlendirmek için işbirlikleri oluşturmaktadır. İşbirliği yapılacak liderlerin belirlenmesinde sosyal ağ teorileri yol gösterici olarak kabul edilmekte ve yapılan davranış bilimi araştırmalarından yararlanılmaktadır (UNDP, 2018)

Etiyopya'daki Berhane Hewan Konseyi programında evlilik yaşının yükseltilmesi için kız çocukların sosyal, sağlık ve ekonomik varlıklarını inşa etmek ve onların dirençlerini arttırmak için kız çocukları, aileleri ve çeşitli toplulukları bir araya getiren çok yönlü davranışsal ekonomi yaklaşımı benimsemiştir (Carter, 2017:9). Program, en azından iki yıllık süre boyunca kız çocukların evliliğini ertelemek için ebeveynler ve kızları arasında gerçekleştirilen bir kamu taahhüdünü içermektedir. Bu süreci başarılı bir şekilde tamamlamaları, evliliğin ertelenmesinin getirdiği finansal dengeyi sağlamak ve katılımı teşvik etmek için ailelere destek taahhüt edilmiştir. Programın yarı deneysel bir değerlendirmesine göre, 10-14 yaş grubundaki çocukların evlenmelerinin geciktirildiği ve aile planlaması hizmetlerinin kullanımını artırdığı görülmüştür (Erulkar ve Muthengi, 2009).

Başka bir örnek olarak Hindistan Bihar'da çocuk evliliğini önlemek ve ilk çocuk sahibi olma yaşını geciktirmek için geliştirilen PRACHAR'da yine bir davranışsal ekonomi programıdır. Program, toplum ve aile üyelerini etkilemeyi ve evliliğin ertelenmesi için sosyal baskıyı teşvik etmeyi amaçlayan bir bileşene sahip olup, 1519 yaşlarındaki gençleri, ebeveynlerini ve toplumu hedeflemiştir. Kırsal Bihar'daki PRACHAR projesi, 15-19 yaşlarındaki çocukların evlilik ve ilk doğum yaşını, iletişim çabalarıyla yükseltmeye çalışmıştır. Katılımcıların ve bir kontrol grubunun rastgele kümelenme örneklemesinin yapıldığı retrospektif bir çalışma, PRACHAR'ın evlenme ve ilk doğum yaşlarını geciktirdiğini düşündürtmüştür (Daniel ve Nanda, 2012).

Medya ise çocuk gelin sorunu ile mücadelede bir yandan sorunun temsilinde toplumsal ayna işlevi üstlenmesi, diğer taraftan toplumsal farkındalığa katkı sağlaması nedeniyle, söz konusu sorunla mücadelede toplumsal bir işleve ve 
sorumluluğa sahiptir. Bir başka deyişle sorunun medyada temsili, gerek durumun tespiti ve toplumsal algının değerlendirilebilmesi, gerekse davranışsal içgörünün harekete geçirilmesi bağlamındaki rolü nedeniyle önem taşımaktadır.

\section{Araştırmanın Amacı}

Medyanın gerek toplumsal yansıma sağlama niteliği gerekse gündemi oluşturma ve farkındalık yaratma konusundaki işlevi nedeniyle, çocuk gelin ve çocuk evlilikleri sorununun medyada temsili önem taşımaktadır. Bu yaklaşımla araştırmanın amacı çocuk gelin ve çocuk evliliklerinin medyada temsil biçimi ile soruna ilişkin farkındalık yaratmaya yönelik etkinliklerin medya yansımalarını anlamaya ve Davranışsal Halkla İlişkiler bağlamında medyanın rolünü değerlendirmeye yöneliktir.

\section{Araştırmanın Örneklemi ve Yöntemi}

Araştırma kapsamında Medyatava verilerine göre en yüksek tiraja sahip olan Hürriyet gazetesi seçilmiştir. Araştırmada 2017 yılı 1 Ocak - 31 Aralık tarihleri arasında Hürriyet gazetesinde "Çocuk Gelin" ile "Çocuk Evlilik" ve "Çocuk Şiddet" anahtar sözcükleri bağlamında online arşiv taraması gerçekleştirilmiştir. "Çocuk Şiddet" sözcükleri kapsamında ulaşılan haberler içerisinde "çocuk gelin" ve "çocuk evliliğini" konu alan haberler tespit edilmiştir. İçerik analizi sonucunda yedi konu başlığı belirlenmiş bazı haberler ise birden fazla kategoriye dahil edilmiştir. Örneğin "İstismar mağduru 13 yaşındaki kız çocuğuna kürtaj” başlıklı haber hem şiddet hem sağlık hem de eğitim hakkından yoksun kalmak kategorilerinde değerlendirilmiştir. Tabiidir ki çalışma sınırlılıklar kapsamında yapılan bir değerlendirmedir. Hürriyet gazetesinin sadece belirtilen tarihler arasındaki haberleri ele alındığı gibi diğer gazeteler örneklem dışıdır. Haber filtrelemesinde Hürriyet gazetesinin kullandığı teknolojiye güvenilerek ulaşılan haberler çalışmada yer almıştır. Anahtar sözcüklerle yapılan aramada elde edilen manșetler ve haberin tamamı okunarak sorunun medyada temsil biçimi, analiz edilmiştir. Sosyal medyada çocuk gelin ve çocuk evlilik haberleri örneklem dışında bırakıldığı için bundan sonraki çalışmaların bu alanda yapılması yararlı olacaktır.

Araştırma kapsamında aşağıdaki sorulara yanıt aranmıştır:

1. Çocuk gelin ve çocuk evliliklerin ilişkin haberler hangi konular altında ele alınmaktadır?

2. Çocuk gelin ve çocuk evliliklerin sonuçları haberlerde yer bulmakta mıdır?

3. Çocuk gelin ve çocuk evliliklerine ilişkin farkındalık yaratmaya yönelik etkinlikler medyada yer bulmakta mıdır?

"Çocuk evlilik (ÇE)" anahtar sözcükleriyle ulașılan 14 haber, "Çocuk Gelin (ÇG)" anahtar sözcükleriyle ulaşılan 21 haber bulunmaktadır. "Çocuk Şiddet (ÇŞ)” anahtar sözcükleriyle yapılan arama sonucunda ise "çocuk gelin" - "çocuk evliliği" konusunu içeren 14 habere ulaşılmıştır. Her üç anahtar sözcükle yapılan aramada 49 habere ulaşılmıştır. Araştırma sırasında haber takibi vb. nedenlerle beş haberin iki kez yayınlandığı görülmüştür.

49 haber 7 temel konu başlığı altında ele alınmıștır (Tablo II). Söz konusu haber başlıkları Çocuk Evlilikleri ve Projeler/Etkinlikler-PE, Uzman Görüşleri ve Araştırma Sonuçları-UA, Dünyadan Haberler-DH, Sağlık (Hamilelik)-SH, Eğitim Hakkından 
Yoksun Kalmak-EH, Şiddet-Ş, Bireysel Tercihler-BT biçiminde kodlanmış ve haberlerin yer aldığı kategoriler Tablo 1'de gösterilmiştir.

Tablo 1: Hürriyet gazetesinde 2017 yılı 1 Ocak- 31 Aralık döneminde yer alan çocuk gelin / çocuk evliliği haberleri

\begin{tabular}{|c|c|c|c|}
\hline Haber tarihi & Haber başlığı & Anahtar Sözcük & Haber Kodu \\
\hline 2.1.2017 & Edirne'de öğrencilere, ‘erken yaşta evlilik' semineri & ÇE & PE \\
\hline 18.1.2017 & Edirne'de okullarda 'erken yaşta evlilik' semineri & ÇE & PE \\
\hline 27.1.2017 & Kayıp kız, 75 gün sonra bulundu & ÇE & Ş/BT \\
\hline 04-02-2017 & Olmaz olsun böyle gelenek & ÇE & Ş/EH/BT \\
\hline 15.2.2017 & $\begin{array}{l}\text { Mardin'de ‘çocuk gelin' yapılmak için } \\
\text { kaçırılan genç kız kurtarıldı }\end{array}$ & ÇG & Ş \\
\hline 22.2.2017 & $\begin{array}{l}13 \text { yaşındaki hırsızık zanlısı } 7 \text { aylık hamile } \\
\text { çıktı. } 16 \text { yaşındaki damat aranıyor }\end{array}$ & ÇG & $\mathrm{SH} / \mathrm{S}$ \\
\hline 23.2.2017 & "Çocuk gelinlere hayır" projesine Yalova'da başladı & ÇG & PE \\
\hline 06.03 .2017 & Toplumsal cinsiyet adaleti izindeyiz & ÇŞ & PE \\
\hline 07-03-2017 & $\begin{array}{l}\text { Avukat Şendoğan: Sadece ocak ayında evliliğini } \\
\text { sonlandırmak isteyen } 38 \text { kadın katledildi }\end{array}$ & ÇŞ & PE \\
\hline 08-03-2017 & 30 bıçak darbesine yenilmedi, hayata sıfırdan başlıyor & ÇŞ & $\mathrm{S} / \mathrm{EH} / \mathrm{SH} / \mathrm{BT}$ \\
\hline 08-03-2017 & Ocak ayında 38 kadın katledildi & ÇŞ & PE \\
\hline $10-03-2017$ & $\begin{array}{l}\text { Önce boğazını kesti, sonra kalbinden } \\
\text { bıçakladı... İfadesi kan dondurdu! }\end{array}$ & ÇŞ & $\mathrm{S} / \mathrm{SH}$ \\
\hline $13-03-2017$ & Kadına yönelik şiddet durmadı & ÇŞ & PE \\
\hline 21.03.2017 & Amacımız kadının konumunu güçlendirmek & ÇŞ & PE \\
\hline 25.3.2017 & $\begin{array}{l}\text { Kızı kaçırılan annenin feryadı: Küçük } \\
\text { gelin olmasın, okusun }\end{array}$ & ÇG & Ş/EH \\
\hline 30.3 .2017 & İstismar mağduru 13 yaşındaki kız çocuğuna kürtaj & ÇG & Ş/SH/EH \\
\hline 11.04 .2017 & Berdel yaşarken ölmektir & ÇŞ & UA \\
\hline 12.4 .2017 & Dans ederek çocuk gelin cinayetlerine dikkat çektiler & ÇG & PE \\
\hline 20.4 .2017 & Kiraz dalında güzel' & ÇG & PE \\
\hline 21.4.2017 & $\begin{array}{l}\text { Kiraz'da kız kaçırmaların önlenmesi için } \\
\text { jandarma farkındalık projesi başlattı }\end{array}$ & ÇE & PE \\
\hline 24.04 .2017 & Boşanma davası çıkışı karısına kurşun yağdırdı & ÇŞ & Ş \\
\hline 26.4.2017 & Lisede skandal... Bunu yaptılar & ÇG & PE \\
\hline 3.5 .2017 & Çocuk gelin oldu, hapis yattı, kocası terk etti & ÇG & $\mathrm{S} / \mathrm{SH}$ \\
\hline 11.05 .2017 & Çocuk yaştaki evlilikler, panellerde ele alınacak & ÇŞ & PE \\
\hline 15.5.2017 & $\begin{array}{l}12 \text { yaşında çocuk gelin oldu, } 13 \text { yaşında } \\
\text { kayınpederinin tecavüzüne uğradı }\end{array}$ & ÇG & Ş \\
\hline 18.5.2017 & Genç iletişimciler ‘Çocuk Gelin'lerin sesi oldu & ÇG & PE \\
\hline 22.5 .2017 & Gaziantep’te çocuk evlilikleriyle mücadele & ÇG & PE \\
\hline 01.06 .2017 & Çocukluğu çalınan çocuklar & ÇŞ & UA \\
\hline 1.6 .2017 & Liseliler Pembe'nin Hikayesi'ni anlattı & ÇG & $\mathrm{PE}$ \\
\hline 24.6 .2017 & Çocuk gelinin babasına 5 , kocasına 11 yıl hapis & ÇG & Ş \\
\hline 27.6 .2017 & Çocuk damat cinayetinde şok detaylar! & ÇG & Ş \\
\hline 02.07.2017 & illk dayağı gerdek gecesi yedim & ÇŞ & $\mathrm{S} / \mathrm{SH}$ \\
\hline 24.7 .2017 & Çocuk gelinin cinayetinde anneden şok iddia & ÇG & Ş \\
\hline 21.8 .2017 & Zoraki evlilikten okula dönüş & ÇE & Ş/EH \\
\hline 24.8.2017 & Erken yaşta evlilik mağdurları çözüm istiyor & ÇE & PE \\
\hline 14.09.2017 & $\begin{array}{l}\text { Bursa'da kadınlardan çocuk evliliği } \\
\text { ve şiddet protestosu }\end{array}$ & ÇŞ & PE \\
\hline
\end{tabular}




\begin{tabular}{|l|l|c|c|}
\hline Haber tarihi & Haber başlığı & Anahtar Sözcük & Haber Kodu \\
\hline 14.9 .2017 & $\begin{array}{l}\text { Akraba evliliği bazı toplumlarda serbest, aslında } \\
\text { 18 yaş altındaki çocukları korumak lazı" }\end{array}$ & ÇG & UA \\
\hline 11.10 .2017 & $\begin{array}{l}\text { Hindistan mahkemesi: 18 yaş altındaki } \\
\text { gelinle cinsel ilişki tecavüzdür }\end{array}$ & ÇE & DH \\
\hline 24.10 .2017 & Hijyen ürünleri alamayan kı çocuklarına evlilik & ÇE & DH \\
\hline 5.11 .2017 & $\begin{array}{l}\text { Sosyal medyadan tepki yağdı: 'Şeriat'a göre erkekler } \\
\text { gayrimeşru doğan kı çocuklarıyla evlenebilir’ }\end{array}$ & ÇE & DH \\
\hline 16.11 .2017 & Hayalini kurduğu üniversite sıralarında eğitim veriyor & ÇE & EH \\
\hline 24.11 .2017 & $\begin{array}{l}\text { Öğrenciler, ‘kadına şiddetı ile ‘çocuk gelin'e } \\
\text { dikkat çekmek için klip hazırladı }\end{array}$ & ÇG & PE \\
\hline 25.11 .2017 & $\begin{array}{l}\text { Diyarbakırlı doktor, muayeneye gelen } \\
\text { çocuk gelinler için beste yaptı }\end{array}$ & ÇG & PE \\
\hline 27.11 .2017 & $\begin{array}{l}\text { BM Türkiye Temsilcisi: Zorla evlendirilen } \\
\text { kız çocuklarının sonu ölüm oluyor }\end{array}$ & ÇE & UA \\
\hline 27.11 .2017 & 'Çocuk gelin' davasında 18 yıl hapis cezası & ÇG & Ş/SH/BT \\
\hline 7.12 .2017 & Çocuk yaşta evlilik istismardır & ÇE & UA \\
\hline 23.12 .2017 & Küçük kızları korumak için çalışıyoruz & ÇE & DH \\
\hline 25.12 .2017 & $\begin{array}{l}\text { Kız çocuklarını okuldan uzaklaştıran 4 } \\
\text { engel: Mesafe, maliyet sağlık, algı }\end{array}$ & ÇŞ & UA \\
\hline 26.12 .2017 & Reddetti, iç çamaşırı çalındı... Dehşeti yaşadı & Ş/SH \\
\hline
\end{tabular}

Tablo 2: Hürriyet gazetesinde 2017 yılı 1 Ocak- 31 Aralık döneminde yer alan çocuk gelin / çocuk evliliği haberleri dağılımı

\begin{tabular}{|l|c|}
\hline Konu başlıkları & Haber sayısı \\
\hline Çocuk evlilikleri ve projeler/etkinlikler (PE) & 20 \\
\hline Uzman görüşleri ve araştırma sonuçları (UA) & 6 \\
\hline Dünyadan haberler (DH) & 4 \\
\hline Sağlık (Hamilelik) (SH) & 8 \\
\hline Eğitim hakkından yoksun kalmak (EH) & 6 \\
\hline Şiddet (Ş) & 18 \\
\hline Bireysel tercihler (BT) & 4 \\
\hline
\end{tabular}

Belirlenen başlıklar altında yer alan haberler incelendiğinde, etkinlik haberlerinin sayısının 20 olduğu görülmektedir. Haberler nedenleri ve sonuçları açısından ele alındığında, 18 haberde şiddete (suça yönelim, cinsel saldırı, çocuk kaçırılması, tecavüz sonucu evlilik ve fiziksel şiddet haberleri), 8 haberde erken evlilik nedeniyle oluşan hamilelik ve sağlı problemlerine, 6 haberde eğitim hakkından yoksun kalma konusuna, 6 haberde uzman görüşlerine, 4 haberde dünyada yapılan çocuk gelin ve çocuk evlilikleri haberlerine, 4 haberde ise bireysel tercihlerle yapılan çocuk evliliklerine değinildiği görülmektedir. Çocuk evliliklerin neden olduğu sonuçlara (sağlık -hamilelik-, eğitim hakkından yoksun kalmak, şiddet) 32 haberde yer verilmiștir.

\section{Araştırma Bulgularının Değerlendirmesi}

TÜİK verilerine göre 2017 yılında Türkiye'de toplam 569.459 evlilik yapıldığı, yine TÜİK verilerine göre bu evliliklerin yüzde 4,2'sinin çocuk evlilikleri olduğu göz önünde bulundurulduğunda, 2017 yılında resmi kayıtlar kapsamında 16-17 yaş grubunda evlenen kız çocuklarının sayısı 23.917 olarak hesaplanmaktadır. Yapılan araştırmada, 2017 yılında tirajı en yüksek gazete olan Hürriyet gazetesinde yer verilen çocuk gelin ve çocuk evliliği haberlerinin sayısının 49 
olduğu sonucuna ulaşılmıștır. Çocuk evliliğinin İzmir, Diyarbakır, Erzurum, Adana, Kahramanmaraş, Karabük gibi farklı illerde yaşandığı görülmüştür. "Çocuk damat cinayetinde şok detaylar!" başlıklı haber ise toplumda hem kız ve hem erkek çocukları arasında yaşanan çocuk evliliklerin de olduğunu göstermektedir. Haber içeriklerinden dünyanın farklı ülkelerinde çocuk evliliği sorununun yaşandığı da dikkati çekmektedir. Mevcut verilerle ulaşılan rakamlar, çocuk gelin ve çocuk evliliğinin Türkiye açısından önemli bir sorun olduğunu, medyada yer bulduğunu, ancak sorunun evrensel, toplumsal ve bireysel etkilerinin büyüklüğü oranında medyada temsil edilmediğini ortaya koyar niteliktedir.

"Çocuk gelin ve çocuk evliliklerine ilişkin haberler hangi konular altında ele alınmaktadır? " Sorusu bağlamında yapılan değerlendirme kapsamında çocuk gelin ve çocuk evliliklerine ilişkin haberlerin; proje ve etkinlikler, uzman görüşleri, sorunla ilgili farklı ülkelerden haberler, evliliklerin neden olduğu sonuçları kapsayan sağlık, eğitim hakkından yoksun bırakılmak, şiddet ile bireysel tercih olmak üzere 7 temel konu altında ele alınabileceği görülmektedir. Çocuk gelin ve çocuk evliliklerin neden olduğu sonuçların gerek uzman görüşleri gerekse haberlerin içeriği bağlamında dağılımına bakıldığında en fazla şiddet, ikinci olarak sağlık problemleri ve ardından eğitim hakkından yoksun bırakılmak ana başlıkları altında ele alınabilecek biçimde medyada temsil edildiği sonucuna ulaşılmaktadır. Uzman yorumları ile soruna ilişkin araştırmalara dair haberlerin sayısının oldukça düşük olması (6/49) ise çocuk gelin sorununa çözüm üretilmesinde ekonomik ve politik nedenlerin medyada önemi oranında tartışılmadığı sonucunu ortaya koyar niteliktedir. "Bireysel tercih" ifadesi ise, özgür iradeyle verilen kişisel karara işaret eder nitelikte bir algıya neden olsa bile, fiziksel ve düşünsel açıdan çocuk olarak nitelenen bireylerin evlilikleri konusunda geçerliliğinin ayrıca sorgulanması gerekir.

"Çocuk gelin ve çocuk evliliklerin sonuçları haberlerde yer bulmakta mıdır?" sorusu kapsamında yapılan değerlendirmede; 49 haberin 32 'sinde sağlık, eğitim hakkından yoksun bırakılma ve şiddet gibi çocuk gelin sorununun neden olduğu sonuçların ele alınmış olduğu görülmektedir. Araştırmadan elde edilen bu veriler ışığında çocuk gelin ve çocuk evliliği sorununun neden olduğu sonuçların medyada yer bulduğu, verilen haberlerin sorunun gündeme taşınması, toplumsal farkındalık yaratılması açısından bir işlev üstlenebileceği yorumuna varılabilir. Bununla birlikte, çocuk gelin ve çocuk evlilikleri sorununun medyada toplumsal ya da evrensel boyutlarından daha çok bireysel sonuçları bağlamında temsil edilmiş olduğu da belirtilmelidir.

"Çocuk gelin ve çocuk evliliklerine ilişkin farkındalık yaratmaya yönelik etkinlikler medyada yer bulmakta mıdır?" sorusu ise 2017 yılında yaşanan 23.917 çocuk gelin ve çocuk evliliğine karşın sorunun medyada 49 haberle temsil edildiği göz önüne alınarak yorumlanabilir. Bu yaklaşımla söz konusu toplam 49 haberin yarıya yakın biçimde 20'sinin gerçekleștirilen etkinliklere ait olması, Davranışsal Halkla İlişkiler programları kapsamında yapılacak etkinliklerin medyada yer bulma olasılığının yüksek olacağı yorumuna ulaştırmaktadır.

\section{Sonuç ve Öneriler}

Çocuk gelin haberlerinin Hindistan ve Mısır gibi ülkelerin de gündeminde bulunması, BM ve UNICEF gibi uluslararası kuruluşların soruna çözüm üretme çabası içerisinde olmaları, ancak Almanya gibi gelişmiş bir ülkede dahi çözüm arayışlarının önemsenmesi çocuk gelin ve çocuk evliliklerinin evrensel 
boyutunu ortaya koyar niteliktedir. Soruna çözüm üretebilmek ise sadece yasal düzenlemelerin yapılması ve toplumsal politikaların geliştirilmesiyle değil, yapılan yasal düzenlemelere ve kamu politikalarına yönelik ortak bilincin oluşturulması ve rasyonel gerekçelerin benimsenmesiyle gerçekleşebilir. Nitekim gelişmekte olan ülkelere yönelik olarak sürdürülen davranışsal içgörü programları bu durumun somut kanıtları olarak değerlendirilebilir.

Türkiye'de 2017 yılında yapılan 569.459 evliliğin TÜİK verilerine göre yüzde 4,2'lik oranını kapsayan 18 yaş altı çocuk evliliklerinin sayısının 23.917 olması, sorununun boyutlarına dikkat çekmektedir. Araştırma sonucunda ulaşılan veriler medyada yer alan haberlerin çocuk gelin ve çocuk evliliklerin şiddete yol açtığı, eğitimden yoksun kalmaya ve anne - çocuk açısından sağlık sorunlarına neden olduğu gösterir niteliktedir. Bu bağlamda sorunun medyada temsilinin sorunun yol açtığı problemler bağlamında gerçek durum ile örtüştüğü söylenebilir.

Kız çocukların okullaşma oranı ile çocuk gelin - çocuk evlilikleri arasında ters orantı olduğu TÜİK verilerinden de anlaşılmaktadır. Bu nedenle kız çocuklarının okulda kalma sürelerinin uzaması, sadece sorunla bireysel mücadele açısından değil, toplumsal kalkınma ve toplumsal refah açısından da bir zorunluluktur. Devlet parasız yatılı okulların sayısının arttırılması, kesintisiz ve zorunlu eğitim süresinin uzatılması gibi tedbirler ile okullaşma oranının arttırılması, istihdam olanaklarının yaratılması ve kadının işgücüne katılmasının sağlanması için yasal düzenlemeler yapılması, cinsiyet eşitsizliğinin yarattığı açığı giderebilmek açısından sorunla mücadelede öncelikli konulardır. Türkiye'nin de imzalamış olduğu Birleşmiş Milletler Bin Yıl Kalkınma Hedefleri arasında çocuk ve anne ölüm oranlarının düşürülmesi, herkese temel eğitim olanaklarının sağlanması, şiddetin önlenmesi, cinsiyet eșitliğinin sağlanması gibi konularda gerekli düzenlemelerin yapılması ve BM 2030 Gündeminde yer alan maddelerin benimsenmesinin çocuk evliliklerinin önlenmesine doğrudan katkı sağlayacağı görülmektedir. Çocuk gelin ve çocuk evliliği aynı zamanda çocuğa yönelik bir şiddet sorunudur, hem fiziksel hem duygusal şiddete yol açan bu durumu araştırma sonuçları da ortaya koymaktadır.

Cinsiyet eşitliğini kabul eden politikanın oluşturulması, kadının iş yaşamına ve sosyal yaşama katılmasının desteklenmesi, okullaşma oranının arttırılması, çağdaş eğitim becerilerinin kazandırılması, kız çocuklarının eğitim hakkının engellenmesinin önüne geçilebilmesi ve köklü çözümler üretilebilmesi için yasal düzenlemeler (Balta Peltekoğlu ve Tozlu, 2017, 16-18) gereklidir. Ancak demokratik ve kalkınmış ülkelerde yasaların kabul görmesi toplumsal ortak bilincin oluşmasıyla gerçekleşir. Nedenleri ve sonuçları itibariyle çok yönlü ele alınması gereken sorunun çözümünde ortak çözüm arayışı ise, mevcut sistem içerisinde Çalışma, Sosyal Hizmetler ve Aile Bakanlığı, Adalet Bakanlığı, EkonomiTicaret Bakanlığı, Kültür ve Turizm Bakanlığı, Milli Eğitim, Sağlık Bakanlığı gibi ilgili bakanlıklar arasında koordinasyon sağlayacak bir yapılanma ve ilgili kamu kurumları, yerel yönetimler ve STK'lar ile ișbirliği kapsamında geliştirilecek kamu politikaları ile söz konusu olabilir. Kurumlar arası işbirliğiyle geliştirilecek çözüm önerilerinin istenen tutum ve davranış değişikliğine dönüşebilmesi ise davranışsal içgörü programlarıyla beslenen Davranışsal Halkla İlişkiler programlarının kamu politikalarıyla bütünleşmesiyle olanaklıdır. 
Bu bağlamda Patrick Jackson'ın davranış değişikliği üzerine odaklanan Halkla İlişkiler modelindeki beş temel adımdan yararlanılabilir ve bu adımlar; çocuk gelin ve çocuk evliliklerine yönelik toplumsal farkındalığın yaratılması, insanların çocuk gelin sorununun neden ve sonuçlarına yönelik edindikleri bilgiler üzerinde düşünmeye başladıkları örtük ilgi sürecinin oluş(turul)ması ve bu ilginin Halkla İlişkiler etkinlikleriyle yapılan yasal düzenlemelere ve haklara ilişkin toplumsal bilincin oluşturulması, sorunun bireysel ve toplumsal etkilerinin anlaşılmasının sağlanması, tutum ve davranış değişiklikleri üzerine düşünme becerisinin geliştirilmesinin sağlanması ve nihayet sorunun bireysel ve toplumsal etkilerinin kavranarak sorunla mücadele etmeye ve başa çıkmaya yönelik davranış değişikliğinin gerçekleşmesi temel alınarak tasarlanabilir. Davranış değişikliği sürecinde karşılaşılabilecek dirençle başa çıkabilmek için ise davranışsal iletişimin temel amacı olan bireyler arasında duygu, düşünce ve gereksinim farklılıklarını tespit ederek ikna temelli, kişiselleştirilmiş, açık, anlaşılır mesaj stratejileri oluşturulmalıdır.

Medyanın toplumsal ayna işlevi ile toplumu bilgilendirme sorumluluğunun bilincinde olması ise soruna çözüm üretilmesi sürecinde önemli katkı sağlayacaktır. Medya, çocuk gelin ve çocuk evlilikleri sorununda sadece bir iletişim kanalı olarak değil, toplumsal duyarlılık yaratılması konusunda da sorunun neden ve sonuçlarına ilişkin araştırmalar ve çözüm önerileri üreten vb. çalışmalarla, davranışsal içgörü programının bir aktörü olarak aktif rol oynayabilir.

Araştırmada elde edilen veriler ışığında Türkiye'de gerçekleşen 23.917 çocuk gelin vakasının medyaya yeterli oranda yansımadığı yorumu da yapılabilir, bununla birlikte araştırma ile ulaşılan haberlerin, sorunun neden olduğu sonuçlar açısından mevcut durumu ortaya koyar nitelikte olduğu görülmektedir. Etkinlik haberlerinin oranının yüksek olması ise, davranışsal Halkla İlişkiler bağlamında atılacak adımların medya ile yapılacak işbirliğiyle farkındalık konusunda istenen etkiyi yaratabileceğinin bir göstergesi olarak yorumlanabilir. Bu yaklaşımla; çocuk gelin ve çocuk evlilikleri sorununa ilişkin çözümün, ilgili bakanlık ve kurumların işbirliğiyle yapılacak yasal düzenlemeler ve alınacak ekonomik tedbirlerin yanı sıra, karşılaşılabilecek direncin farkında olan, ortak bilincin oluşturulmasını hedefleyen ve medyanın desteğini alan Davranıșsal Halkla İlişkiler programlarının kamu politikaları içinde yer bulmasıyla olanaklı olduğu söylenebilir.

\section{Kaynakça}

Balta Peltekoğlu F. (2000). Halkla İlişkiler Eğitimi Nasıl Olmalı, Halkla İlişkiler Forum VIII. Kongresi'nde sunulan bildiri, 31 Ekim 2000, İstanbul

Balta Peltekoğlu F. (2005). Halkla İlişkiler Nedir, İstanbul: Beta Yay.

Balta Peltekoğlu F. (2016). Halkla İlişkiler Üzerine Düşünmek, (Ed.) Filiz B. Peltekoğlu, , İletişimin Gücü içinde, (369-384). İstanbul: Beta Yay.

Balta Peltekoğlu F. \& Tozlu, E. (2017). Medya Yansımaları Ekseninde Kadına Şiddet Sorunsalı ve Halkla İlişkiler. Marmara İletişim Dergisi, 28, 1-19.

Balta Peltekoğlu F. (2018). Halkla İlişkiler Nedir, İstanbul: Beta Yay.

Behavioral Insights in Canada. (2018). Erișim Adresi: https://www.bicanada18. com/what-is-behavioural-insights/ 
Child Marriage. (2018). UNICEF. Erişim Adresi: http://unicef.in/Whatwedo/30/ Child-Marriage

Child Marriage Around the World. (2018). UNICEF. Erişim Adresi: https://www. uniceforg/stories/child-marriage-around-world

Center, A. H., Jackson, P., Smith, S., \& Stansberry, F. R. (2008). Public relations practices: Managerial case studies and problems. Pearson Prentice Hall.

Çocuk Haklarına Dair Sözleșme: Birinci Kısım Madde 1-20. (1989). Erișim Adresi: https://www.unicef.org/turkey/crc/_cr23c.html

Çocuk Koruma Kanunu, (3 Temmuz 2005), (Resmi gazete: 25876). Erişim Adresi: http://www.mevzuat.gov.tr/MevzuatMetin/1.5.5395.pdf

Daniel, E. E., \& Nanda, R. (2012). The effect of reproductive health communication interventions on age at marriage and first birth in rural Bihar India: a retrospective study. Pathfinder International Research and Evaluation Working Paper Series. Erişim Adresi: https://www.pathfinder.org/wp-content/ uploads/2016/11/The-Effect-of-Reproductive-health-CommunicationInterventions-on-Age-at-Marriage-and-First-Birth-in-Rural-Bihar-India.pdf

Erulkar, A. S., \& Muthengi, E. (2009). Evaluation of Berhane Hewan: A program to delay child marriage in rural Ethiopia. International Perspectives on Sexual and Reproductive Health, 6-14.

EU Science HUB. (2018). Erişim Adresi: https://ec.europa.eu/jrc/en/research/ crosscutting-activities/behavioural-insights

Flynn, T. (2015). How narratives can reduce resistance and change attitudes: Insights from behavioral science can enhance public relations research and practice. Research Journal of the Institute for Public Relations, 2(2), 1-25.

Flynn, T. (2016). Erişim Adresi: https://instituteforpr.org/ipr-behavioral-insightsresearch-center/

Girls Not Brides. (2018). Erişim Adresi: https://www.girlsnotbrides.org/why-doesit-happen/

Hürriyet Gazetesi. (27 Ocak 2016). Tunceli'nin eğitimdeki liderliğini kaptırmak istemiyoruz. Erişim Adresi: http://www.hurriyet.com.tr/egitim/tuncelininegitimdeki-liderligini-kaptirmak-istemiyoruz-40045773

Internal Revenue Services. (2016). Erişim Adresi: https://www.irs.gov/pub/irssoi/17rpirsbehavioralinsights.pdf

IPR. (2018). Erişim Adresi: https://instituteforpr.org/behavioral-insights-researchcenter/about-birc/

IWCH. (2018). Erişim Adresi: https://iwhc.org/resources/facts-child-marriage/

İstatistiklerle Çocuk 2016. (2017). Erişim Adresi: http://www. cocugasiddetionluyoruz.net/wp-content/uploads/haber_bulteni.pdf

İstatistiklerle Çocuk 2017. (2018). Erișim Adresi: www.tuik.gov.tr/PdfGetir. do?id=27596

Nour, N. M. (2009). Child marriage: a silent health and human rights issue. Reviews in obstetrics and gynecology, 2(1), 51-56 
Nüfus Bilim Derneği. (2007). Erişim Adresi: http://www.nd.org.tr/images/ other/245.pdf

OECD. (2018). Erişim Adresi: http://www.oecd.org/gov/regulatory-policy/ behavioural-insights.htm

Raj, A. (2010). When the mother is a child: the impact of child marriage on the health and human rights of girls , Archives of Disease in Childhood , 95, 931-935.

TheBehavioralInsights Team.(2018).ErişimAdresi:http://www.behaviouralinsights. co.uk/about-us/

The Pixel Project's "16 For 16" Campaign. (6 Aralık 2013). Erişim Adresi: http://16days.thepixelproject.net/16-organisations-working-to-stop-childmarriage/

The World Bank. (2018). Erișim Adresi: http://www.worldbank.org/en/programs/ embed

Türk Ceza Kanunu. (26 Eylül 2004). (Resmi Gazete: 25611) Erişim Adresi: http:// www.mevzuat.gov.tr/MevzuatMetin/1.5.5237.pdf

Türk Medeni Kanunu. (22 Kasım 2001). (Resmi Gazete: 24607) Erişim Adresi: http://www.mevzuat.gov.tr/MevzuatMetin/1.5.4721.pdf

UNDP. (2018). Behavioral Insights at the United Nations. Erişim Adresi: https:// www.undp.org/content/dam/undp/library/innovation/Behavioral\%20 Insights $\% 20$ at $\% 20$ the $\% 20$ UN.pdf

US Department of Labour. (2018). Erişim Adresi: https://www.dol. gov / as p / evaluation / completed-studies / BI-Files / 6a-50291CommunicationsChecklistHandout-Color-20170501.pdf

Veri Kaynağı. (2018) Erişim Adresi: https://www.verikaynagi.com/konu-basligi/ orgun-egitim-istatistikleri 